\title{
Evaluation of body-self-perception of sedentary individuals aged over 30 who attended fitness center classes
}

\author{
Mahmut GULlE ${ }^{1}$ Gulten HERGUNER ${ }^{2}$, Mehmet Cagri CETIN¹, \\ Engin GEZER ${ }^{1}$,
}

${ }^{1}$ School of Physical Education and Sports, Mustafa Kemal University, Hatay, Turkey.
${ }^{2}$ School of Physical Education and Sports, Sakarya University, Sakarya, Turkey.
Address correspondence to Mahmut Gülle, mhmtgulle@gmail.com

Abstract

With this study; it was aimed to obtain multi-dimensional evaluation of body-self perception levels of sedentary individuals aged over 30 who attended fitness center classes. The population of the study was consisted of fitness centers located in Hatay Province. The sample was composed of 80 sedentary individuals (38 men and 42 women) who attended the selected fitness centers with random sampling. All of the subjects were included in the study with voluntariness principle. Pre-test and posttest method was used in order to conduct a more illustrative study. In the study; a personal information form designed by the researcher and "The Multidimensional Body-Self Relations Questionnaire" which was designed by Winstead and Cash and Turkish adaptation and new form of which was made by Dogan and Dogan were administered to the subjects. Means, standard deviations of all the data were calculated. Comparisons of pre-test and post-test scores of the subjects were made with Paired Samples $\mathrm{t}$ - test. It was checked whether or not the results were significant at 0.05 level and 0.01 level. As a result; there was significant difference in terms of gender whereas no difference existed in terms of age, economic status and educational status. Again; when pre-test and post-test scores with regard to the subscales of "The Multidimensional Body-Self Relations Questionnaire" were compared no significant difference was found.

Key Words: Body perception, sedentary, self-respect.

\section{INTRODUCTION}

Although today; poor amount of movement is defined as a disease; it is considered as a factor that increases cardio vascular diseases. It may be argued that poor amount of movement not only causes diseases in people's lives but also affects their psychological self-respect levels and social life levels. Socialization perception, being an important part of world order, means interpersonal dialogue integrity thanks to self-confidence.

Due to leading a sedentary life style; excess weight occurs in people's bodies and thus the existing dissatisfaction with their bodies are negatively reflected upon their self-confidence and self-concept. As a result; a deficiency occurs in psychological perception levels towards themselves. Self-concept is the whole of experiences which may be explained by "all that belongs to $\mathrm{me}^{\text {" in }}$ phenomenological perception area. People's sense of self includes their opinions, perceptions and beliefs about themselves (5). Self-concept may be defined as people's own ideas individually produced in order to perceive or evaluate themselves. Self-concept is all of the ideas and evaluations people have about who they are. People's evaluations on themselves make up their real personality (29). Self-concept is a term created by our opinions about ourselves and by our point of views. Therefore; self-concept can be defined as a special part of personality. In short; selfconcept -named as a dynamic umbrella that includes people's opinions about their abilities, values and ideals- is individuals' awareness of their own identity $(11,12)$. An individual with a healthy selfconcept accepts their weak and strong sides through evaluations made by the environment. People with high self-concept make fewer errors and are more successful; thus may feel more valuable (21). For Chrzanowski; natural traits of people like intellect, image, and body structure are the properties that constitute self-esteem. Life experiences, culture, social order, family and environmental factors play a role in the formation of this concept, too (4). Sportive activities are a helpful way that improves people's 
both body and psychological health and enables them to detect their own physical abilities and to learn their own strengths. At the same time; individuals learn to compete with themselves, nature, time and others and as a result learn that both winning and losing are acceptable. Necessity to obey certain rules, corporation and helping each other, respect for others' rights, satisfaction with and confidence in belonging to a group are just some of the examples of many achievements that can be obtained with sportive activities (20).

Many studies point out that there are benefits of physical activities on mental health and physical activities serve to improve psychological functions of individuals (1). Many studies emphasize that people have worries about body structure and image. When an individual, who is under the influence of body image accepted as ideal by the effect of culture and fashion, experiences a conflict between the ideal body image and his own body image; it may be argued that it directly affects his/her self-esteem. According to Güçlü and Yentür; Richman and Shaffer; participation in sportive activities increases and affects body perception and satisfaction positively $(9,23,14)$. For Çelik and Tritshler talks about another benefit of physical activity and suggests that an individual respects his/her own body and thus respects himself/herself $(3,26)$. Physical activities are important in the sense that they decrease risks of many different diseases and thus the encouragement of physical activities reinforces public health. Physical activities play key roles in individuals' physical, mental and social well being as well as increase quality of life $(10,27)$.

\section{MATERIAL AND METHOD}

\section{Study Model}

In the present research; general survey modelone of the descriptive study methods- was used. Survey method is a research model used on the purpose of representing the existing condition (13).

\section{Population and Sample}

The population of the study was consisted of fitness centers located in 2013 Hatay Province. The sample was composed of 80 individuals ( 38 men and 42 women) who did sports at the selected fitness centers and were selected with random sampling. To the participants; "Scale of multi-directional bodyego relations" was administered twice. First; the pretest was administered in the first week when they started to do sports at the fitness center classes and the post-test was administered in the last week of third month. Those who represented the sample group were registered by the researcher into the computer to follow whether or not they attended fitness center classes regularly. Mean height of the participant women was $163 \mathrm{~cm}$ while mean height of the participant men was $174.5 \mathrm{~cm}$. It was found out that mean weight of the participant women was 76 $\mathrm{kg}$ while mean weight of the participant men was 83 $\mathrm{kg}$ and these values were written down survey forms. During the study; body mass index of the participants were calculated using the BMI formula of World Health Organization.

\section{Data Collection Tools}

\section{The Multidimensional Body-Self Relations Questionnaire- MBSRQ}

The Multidimensional Body-Self Relations Questionnaire- MBSRQ was designed by Winstead and Cash and is a questionnaire with 140 items which assesses attitudinal dispositions towards body image. The scale was transformed into a short form of 54 items and 9 items related with body areas and 6 items related with body weight were included (28). In our study; this form of Multidimensional Body-Self Relations Questionnaire- MBSRQ of 57 items which was consisted of psychological attitude (evaluative, cognitive, and behavioral components) and body attitude (physical appearance, body's competence, biological integrity) was used. There are seven subscales in Multidimensional Body-Self Relations Questionnaire- MBSRQ: Appearance Evaluation (5, 9, 17, 23, 32, 40). Appearance Orientation (1, 2, 10, 18, 24, 25, 33, 34, 41, 42). Physical Competence Evaluation (3, 11, 19, 26, 35, 43). Physical Competence Orientation $(4,12,13,20$, 27, 28, 36, 44, 45). Fitness, and Health/Illness Evaluation (6, 14, 21, 29, 37, 46). Fitness, and Health/Illness Orientation $(7,8,15,16,22,30,31,38$, $39,47,48)$. Body Areas Satisfaction (49, 50, 51, 52, 53, $54,55,56,57) .12^{\text {th }}, 13^{\text {th }}, 14^{\text {th }}, 2^{\text {th }}, 26^{\text {th }}, 27^{\text {th }}, 29^{\text {th }}, 30^{\text {th }}$, $31^{\text {st }}, 33^{\text {rd }}, 35^{\text {th }}, 37^{\text {th }}, 39^{\text {th }}, 40^{\text {th }}, 41^{\text {st }}$ items were reverse worded. Addition of the scores obtained from items provides total score of the questionnaire. In Turkish form of the questionnaire, one can get a minimum score of 57 and a maximum score of 285 . This score is also mean item score of the so called subscale. Accordingly; mean subscale score of a subject may be minimum 1 and maximum 5 The Multidimensional Body-Self Relations Questionnaire- MBSRQ is a questionnaire of 57 items developed to assess attitudinal dispositions towards body image. 


\section{Data Analyses}

In the study; the analyses of the data obtained through data collection tools were performed with SPSS 15.00 package program. While analyzing the data related with personal characteristics; such descriptive statistics methods as frequency (n), percentages $(\%)$, arithmetic means $(X)$ and standard deviation (sd) were used. In order to find out the difference; $t$ - test was used because the data followed a normal distribution and homogeneity conditions was obtained. The results were accepted as significant at 0.05 and 0.01 significance level.

As seen in Table 1; the number of the male participants was 38. After minimum age (32.0) and maximum age (52.0) of the male participants were found, mean age was calculated as 40.47. The number of the female participants was 42. After minimum age (30.0) and maximum age (55.0) of the female participants were found, mean age was calculated as 38.95 .

According to the findings presented in Table 2 and compared test results of the participant individuals; it was explored that there was a significant difference between Body Mass Index $(\mathrm{p}<0.01)$ and Body Areas Satisfaction $(\mathrm{p}<0.01)$ in terms of pre-test results and post-test results. As for the other subscales of the questionnaire Appearance Evaluation ( $>0.05)$, Appearance Orientation $\quad(p>0.05)$, Physical Competence Evaluation $(\mathrm{p}<0.05), \quad$ Physical Competence Orientation $(p>0.05)$, Fitness, and Health/Illness Evaluation $(p>0.05)$, Fitness and Health/Illness Orientation $(p>0.05)-$; no statistically significant difference existed.

According to the pre-test findings related to gender of the participants that Table 3 demonstrated; it was seen that there was a significant difference in Appearance Evaluation $(p<0.05)$, Physical Competence Evaluation $(p<0.05)$, Physical Competence Orientation $(\mathrm{p}<0.05)$ and Fitness, and Health/Illness Evaluation $(p<0.05)$. However; it was discovered that no difference was found in Appearance Orientation, Fitness, and Health/Illness Orientation and Body Areas Satisfaction. As far as the findings obtained from the body-self relations questionnaire were concerned, it was noted that there was a negative significance against female participants.

Table 1. Minimum and maximum values of the participants in terms of age and gender.

\begin{tabular}{lccccc}
\hline Gender & $\mathrm{N}$ & Minimum & Maximum & Mean & Std. Dev. \\
\hline Male & & & & & \\
Female & 38 & 32.00 & 52.00 & 40.47 & 5.02 \\
& 42 & 30.00 & 55.00 & 38.95 & 7.30 \\
\hline
\end{tabular}

Table 2. Pre-test and Post-test results of the participants in terms of Paired simple $t$ test.

\begin{tabular}{|c|c|c|c|c|c|c|}
\hline Variables & & $\mathrm{N}$ & Mean & Std. Deviation & $\mathrm{t}$ & $\mathrm{p}$ \\
\hline \multirow{2}{*}{ Body Mass Index } & Pre-test & 80 & 26.71 & 2.95 & \multirow{2}{*}{7.442} & \multirow{2}{*}{$.000^{*}$} \\
\hline & Post-test & 80 & 25.66 & 2.93 & & \\
\hline \multirow{2}{*}{ Appearance Evaluation } & Pre-test & 80 & 18.35 & 3.39 & \multirow{2}{*}{.972} & \multirow{2}{*}{.334} \\
\hline & Post-test & 80 & 18.28 & 3.43 & & \\
\hline \multirow{2}{*}{ Appearance Orientation } & Pre-test & 80 & 30.76 & 3.37 & \multirow{2}{*}{1.249} & \multirow{2}{*}{.215} \\
\hline & Post-test & 80 & 30.59 & 3.33 & & \\
\hline \multirow{2}{*}{ Physical Competence Evaluation } & Pre-test & 80 & $17.89^{a}$ & 3.61 & \multirow{2}{*}{---- } & \multirow{2}{*}{---- } \\
\hline & Post-test & 80 & $17.89^{a}$ & 3.61 & & \\
\hline \multirow{2}{*}{ Physical Competence Orientation } & Pre-test & 80 & 27.98 & 3.97 & \multirow{2}{*}{.257} & \multirow{2}{*}{.798} \\
\hline & Post-test & 80 & 27.94 & 3.70 & & \\
\hline \multirow{2}{*}{ Fitness, and Health/Illness Evaluation } & Pre-test & 80 & 16.84 & 3.95 & \multirow{2}{*}{1.114} & \multirow{2}{*}{.269} \\
\hline & Post-test & 80 & 16.69 & 3.79 & & \\
\hline \multirow{2}{*}{ Fitness, and Health/Illness Orientation } & Pre-test & 80 & 33.66 & 5.14 & \multirow{2}{*}{.400} & \multirow{2}{*}{.690} \\
\hline & Post-test & 80 & 33.60 & 4.85 & & \\
\hline \multirow{2}{*}{ Body Areas Satisfaction } & Pre-test & 80 & 24.21 & 4.71 & \multirow{2}{*}{-5.417} & \multirow{2}{*}{$.000^{*}$} \\
\hline & Post-test & 80 & 25.91 & 4.77 & & \\
\hline \multirow{2}{*}{ Total pre-test post-test } & Pre-test & 80 & 188.33 & 23.21 & \multirow{2}{*}{-2.611} & \multirow{2}{*}{.051} \\
\hline & Post-test & 80 & 189.95 & 21.61 & & \\
\hline
\end{tabular}

${ }^{*} \mathrm{p}<0.05$ 
Table 3. Results of t-test performed to assess pre-test results regarding body-self esteem perceptions of the participants in terms of gender.

\begin{tabular}{|c|c|c|c|c|c|c|c|}
\hline Subscale & Gender & $\mathrm{N}$ & Mean & Std. Deviation & $\mathrm{F}$ & $\mathrm{p}$ & $\mathrm{t}$ \\
\hline \multirow[t]{2}{*}{ Appearance Evaluation } & 1.00 & 38 & 19.86 & 3.56 & \multirow{2}{*}{4.390} & \multirow{2}{*}{$.039^{*}$} & \multirow{2}{*}{4.159} \\
\hline & $\begin{array}{l}2.00 \\
1.00\end{array}$ & $\begin{array}{l}42 \\
38\end{array}$ & $\begin{array}{l}16.99 \\
32.16\end{array}$ & $\begin{array}{l}2.59 \\
3.37\end{array}$ & & & \\
\hline Appearance Orientation & 2.00 & 42 & 29.49 & 2.85 & 1.681 & .199 & 3.834 \\
\hline \multirow{2}{*}{ Physical Competence Evaluation } & 1.00 & 38 & 19.50 & 2.94 & \multirow{2}{*}{4.315} & \multirow{2}{*}{$.041^{*}$} & \multirow{2}{*}{4.162} \\
\hline & 2.00 & 42 & 16.44 & 3.57 & & & \\
\hline \multirow{2}{*}{ Physical Competence Orientation } & 1.00 & 38 & 28.55 & 5.17 & \multirow{2}{*}{12.614} & \multirow{2}{*}{$.001^{*}$} & \multirow{2}{*}{1.208} \\
\hline & 2.00 & 42 & 27.48 & 2.38 & & & \\
\hline \multirow{2}{*}{ Fitness. and Health/Illness Evaluation } & 1.00 & 38 & 18.48 & 4.14 & \multirow{2}{*}{6.233} & \multirow{2}{*}{$.015^{*}$} & \multirow{2}{*}{3.842} \\
\hline & 2.00 & 42 & 15.35 & 3.13 & & & \\
\hline \multirow{2}{*}{ Fitness. and Health/Illness Orientation } & 1.00 & 38 & 37.11 & 3.80 & \multirow{2}{*}{.004} & \multirow{2}{*}{.949} & \multirow{2}{*}{7.402} \\
\hline & 2.00 & 42 & 30.54 & 4.09 & & & \\
\hline \multirow{2}{*}{ Body Areas Satisfaction } & 1.00 & 38 & 25.51 & 5.41 & \multirow{2}{*}{3.365} & \multirow{2}{*}{.070} & \multirow{2}{*}{2.406} \\
\hline & 2.00 & 42 & 23.04 & 3.67 & & & \\
\hline \multirow{2}{*}{ Total pre-test post-test } & 1.00 & 38 & 202.18 & 22.80 & \multirow{2}{*}{10.065} & \multirow{2}{*}{$.002^{*}$} & \multirow{2}{*}{6.150} \\
\hline & 2.00 & 42 & 175.79 & 15.17 & & & \\
\hline
\end{tabular}

${ }^{*} \mathrm{p}<0.05$

Table 4 Results of t-test performed to assess post-test results regarding body-self esteem perceptions of the participants in terms of gender.

\begin{tabular}{|c|c|c|c|c|c|c|c|}
\hline Subscale & Gender & $\mathrm{N}$ & Mean & Std. Deviation & $\mathrm{F}$ & $\mathrm{p}$ & $\mathrm{t}$ \\
\hline \multirow[t]{2}{*}{ Appearance Evaluation } & 1.00 & 38 & 19.88 & 3.44 & 1.109 & .296 & 4.401 \\
\hline & 2.00 & 42 & 16.84 & 2.74 & & & \\
\hline \multirow{2}{*}{ Appearance Orientation } & 1.00 & 38 & 31.83 & 3.27 & 1.059 & .307 & 3.365 \\
\hline & 2.00 & 42 & 29.47 & 2.99 & & & \\
\hline \multirow[t]{2}{*}{ Physical Competence Evaluation } & 1.00 & 38 & 19.50 & 2.94 & 4.315 & $.041^{*}$ & 4.162 \\
\hline & 2.00 & 42 & 16.44 & 3.57 & & & \\
\hline \multirow[t]{2}{*}{ Physical Competence Orientation } & 1.00 & 38 & 28.25 & 4.76 & 8.843 & $.004^{*}$ & .700 \\
\hline & 2.00 & 42 & 27.67 & 2.41 & & & \\
\hline \multirow{2}{*}{ Fitness. and Health/Illness Evaluation } & 1.00 & 38 & 18.09 & 4.05 & 7.920 & $.006^{*}$ & 3.345 \\
\hline & 2.00 & 42 & 15.42 & 3.06 & & & \\
\hline \multirow[t]{2}{*}{ Fitness, and Health/Illness Orientation } & 1.00 & 38 & 36.73 & 3.55 & .335 & .564 & 6.942 \\
\hline & 2.00 & 42 & 30.77 & 4.08 & & & \\
\hline \multirow[t]{2}{*}{ Body Areas Satisfaction } & 1.00 & 38 & 27.43 & 5.09 & .565 & .454 & 2.829 \\
\hline & 2.00 & 42 & 24.54 & 4.04 & & & \\
\hline \multirow[t]{2}{*}{ Total pre-test post-test } & 1.00 & 38 & 203.21 & 19.38 & 2.196 & .142 & 6.408 \\
\hline & 2.00 & 42 & 177.95 & 15.83 & & & \\
\hline
\end{tabular}

When the post-test findings related to gender of the participants that Table 4 demonstrated were examined; it was seen that there was a significant difference in Physical Competence Evaluation $(p<0.05)$, Physical Competence Orientation $(p<0.05)$ and Fitness, and Health/Illness Evaluation $(p<0.05)$. Yet; no difference existed in Appearance Evaluation, Appearance Orientation, Fitness, and Health/Illness Orientation and Body Areas Satisfaction. As far as the findings obtained from the body-self relations questionnaire were concerned, it was noted that there was a negative significance against female participants.

\section{DISCUSSION}

This study was conducted to understand whether or not levels of body-self relation differed in terms of pre-test and post-test results among the sedentary individuals who performed physical activities at fitness centers.

According to the study findings; when sedentary individuals were analyzed in terms of their Body Mass Index; it was discovered that mean pre-test scores were higher than mean post-test scores as far as pre-test and post-test results were concerned; which was an unexpected finding of our study. That is; it was considered that it was an expected result that body-self relations of those doing sports would increase. We were of the 
opinion that those doing sports expected that they would have big changes in a short time through doing sports; which was effective upon this result. It was said that those who were sedentary or had weight problems attended sports centers mainly because of their concern with appearance rather than excess weight.

According to the study of Pinar on obese individuals; it was noted that self-respect scores and body-image scores of those doing sports were lower; the reason of which was -Pinar thought- that those attending sports centers in order to lose weight could not obtain the desired results (22). This result was in line with our study. However; in many studies conducted it was pointed out that those doing sports were more satisfied with their bodyself images as compared to those not doing sports $(1,31,32,33,34)$. In a study made by Doll et al., it was argued that disproportional body weight caused mentally and psychologically negative outcomes among the individuals (7).

When the results of pre-test and post-test of subscales of body-self relations questionnaire were examined; it was seen that there was a significant difference in Satisfaction with Body Areas. When the mean scores were investigated, it was found out that pre-test results were lower than post-test results. It was concluded that the reason that amount of satisfaction with Body Areas of the sedentary individuals was higher in pre-test results as compared with post-test results was that they had some insignificant changes in their bodies through doing exercises. According to Celik et al. and Tritshler maintained that primary positive aspect of physical activity was that it increased one's satisfaction with his/her bodies; which meant that any positive change in body brought about by doing sports might provide positive results in their selfperception $(3,26)$.

When the participants' results of subscales of body-self relations questionnaire were examined in pre-test and post-test in terms of gender variable; it was explored that women's mean scores were lower in Appearance Evaluation. It is known than women pay more attention to their body image and body appearance than men (19). According to the findings obtained; it may be suggested that this was a normal outcome that such a result was obtained before women started to do sports. As stated by Chen et al. and Loland too; especially women are more critical about their own bodies and are more concerned with their body weight and appearance and are more dissatisfied with their bodies as compared to men $(15,16)$. In the studies of Martin and Bastug \& Kuru; it was emphasized that doing sports contributed to body appearance. Considering that this finding was related with the results obtained before sedentary individuals started to do sports; it was an expected outcome $(2,17)$. As seen in post-test results of sedentary individuals; that they obtained higher scores in Appearance Evaluation as compared with pre-test indicated that sports played a key role Appearance Evaluation.

According to the pre-test results of the sedentary individuals examined in terms of Physical Competence Evaluation in relation with gender variable; it was seen that there was a significant difference. As far as the findings obtained were concerned; it was concluded that women had lower Physical Competence Evaluation than men. It was seen that our findings concurred with the results of the study of Zekioglu, Sung et al., Tiggemann and Williamson $(24,25,30)$. In other words; in the abovementioned study on sedentary individuals and those not doing sports it was emphasized that men had higher Physical Competence Evaluation than women. When post-test results of the study were analyzed, the difference was at the same level. According to other findings, the amounts of leisure time and physical activity were positively related with body dissatisfaction for girls, but not for men. These discordances might be due to the difference of sample, on the measures of body Image and physical activity $(8,18,25)$.

According to the pre-test results of the sedentary individuals examined in terms of Physical Competence Orientation in relation with gender variable; there was a significant difference against women. When total scores of the participant women were questioned in terms of Physical Competence Orientation; it was seen that they demonstrated low Physical Competence Orientation; the main reason of which -we thought- was that they paid more attention to their physical appearance, had low selfconfidence in case of -even- a small inefficacy/failure and thus had low body perception.

In the studies of Bastug and Kuru (2) and Zekioglu (30); it was discovered those not doing sports had lower scores in Physical Competence Orientation. Our findings were in agreement with these studies. When post-test and pre-test results were examined; it was found out that the difference was at the same level. 
When the pre-test results of the sedentary individuals were examined in terms of Fitness and Health/Illness Evaluation in relation with gender variable; it was seen that there was a significant difference against women. When total scores of the women were investigated; it was noted that these scores were lower than men; main reason for which -we thought- our participant women were mostly housewives and thus spared less time for a healthy life due to leading a sedentary life style. With this result; it may be argued that women are more affected by diseases or health problems. In the study of Buştuğ \& Kuru ; it was found out that Fitness, and Health/Illness Evaluation scores of individuals not doing sports were lower(2) In the study of Zekioğlu; Fitness, and Health/Illness Evaluation scores of female individuals not doing sports were lower than men in terms of gender variable (30). It was noted that our findings were in line with these studies. When post-test results and pre-test results of the study were investigated; it was seen that there was significant difference at the same level.

According to the findings of our study; when results of body-self relations were examined, it was discovered that there was significant difference between the results of sedentary individuals obtained before and after starting sports. As for the body-self relations questionnaire; it was explored that there were significant differences between pretest scores and post-test scores in terms of Physical Competence Evaluation, Physical Competence Orientation and Fitness, and Health/Illness Orientation.

\section{REFERENCE}

1. Aşc1 HF. Sense of self and exercises. Hacettepe J of Sport Sciences, 2004; 15(4): 233-266.

2. Baştuğ G, Kuru E. Bayan sporcuların bedenlerini algılama düzeyleri ve cinsiyet rolleri üzerine bir araştırma, Gazi Üniversitesi, Gazi Eğitim Fakültesi Dergisi, 2009; 29(2): 533555.

3. Çelik VO, Yılmaz İ, Solmaz AR, Yalız D. Kurum içi spor etkinliklerine katılan bayan ve erkek üniversite öğrencilerinin vücut imajı algıları arasındaki farlılık üzerine bir araştırma (Anadolu Üniversitesi örneği). 9. Uluslar arası Spor Bilimleri Kongresi, 2006; 1159, Muğla.

4. Chrzanowski G. The genesis and nature of self-esteem. American Journal of Psychotherapy, 1981; 35(1): 143-151.

5. Cüceloğlu D. İnsan ve Davranışı 7 Baskı. Remzi Kitabevi, İstanbul, 1997.

6. Doğan O, Doğan S. Çok Yönlü Vücut imajı İlişkileri Ölçeği El Kitabı. Cumhuriyet Üniversitesi Yayınları, Cumhuriyet Üniversitesi Tıp Fakültesi Basımevi, Sivas, 1992.

7. Doll HA, Petersen SE, Stewart-Brown SL. Obesity and physical and emotional well-being: associations between body mass index, chronic illness, and the physical and mental components of the SF-36 questionnaire. Obes Res, 2000; 8(4): 160-170.

8. Duncan MJ, Al-Nakeeb Y. Body image and physical activity in British secondary school children. Euro Phys Educ Rev, 2004; 10: 243-60.

9. Güçlü $M$, Yentür J. Milli takım düzeyindeki elit bayan sporcuların kişisel ve sosyal uyum düzeyleri ile bedenlerini algılama düzeylerinin karşılaştırılması. Spormetre Beden Eğitimi ve Spor Bilimleri Dergisi, 2008; 4(2): 183-192.

10. Hamer M, Stamatakis E. Physical activity and risk of cardiovascular disease events: Inflammatory and metabolic mechanisms. Medicine and Science in Sports and Exercise, 2009; 41(6): 1206-1211.

11. İkizler C, Karagözoğlu C. Psychology of Success in Sports. Alfa Publication, Istanbul.1997.

12. Karakoç Ö. Investigation of self-esteem levels of hearing impaired national players and of hearing impaired individuals who did not play sports, Frrat University, Health Sciences Institute Health Sciences Institute, Department of Physical Education and Sports Physical Education and Sports, Master Degree Thesis, Elazı ğ. 2010.

13. Karasar N. Scientific Research Methods. Nobel Publications, Ankara, 2005.

14. Kulaksızoğlu A. Adolescence Psychology. 7 Edition, Remzi Publication, Istanbul, 2005.

15. Li-Jung C, Kenneth RF, Anne MH, Po-Wen K. Correlates of body dissatisfaction among Taiwanese adolescents. Asia Pac J Clin Nutr, 2010; 19(2): 172-179.

16. Loland NW. Body image and physical activity, a survey among Norwegian men and female. International Journal of Sport Psychology, 1998; 29: 339-365.

17. Martin KA, Sinden AR, Fleming JC. Inactivity may be hazardous to your image, the effects of exercise participation on impression formation. Journal of Sport \& Exercise Psychology, 2000; 22(3): 283-291.

18. Mikkila V, Lahti-Koski M, Pietinen P. Virtanen SM, Rimpela M. Associates of obesity and weight dissatisfaction among Finnish adolescents. Public Health Nutr, 2003; 6(1): 49-56.

19. Otaibi AL H. Nassef S, Raouf T. Body shape dissatisfaction, weight status and physical activity among a sample university students in Saudi Arabia. Food and Nutrition Sciences, 2013; 4: 616-625.

20. Öztürk KF. Adana ili orta öğretimde sportif katılımın, benlik saygısı üzerine etkisi. Eğitim Kurumlarında Beden Eğitimi ve Spor II. Ulusal Sempozyumunu, 16-18 Aralık 1993; Manisa.

21. Patrick H, Neighbors CT, Knee CR. Social comparison and body image: the role of contingent self-esteem and selfperceptions of attractiveness. Personality and Social Psychology Bulletin, 2004; 30(3): 501-514.

22. Pinar R. Depression, self-esteem and body image among the obese: a comparative study. C U Nursing School Journal, 2002; 6(1): 30-41.

23. Richman EL, Shaffer DR. If you let me play sport: how might female sports participation influence the self-esteem of adolescent females. Psychology of female Quarterly, 2000; 24:189-199. 
24. Sung RYT, Yu CW, Yani RCH, Lam PKW, Hau KT. Selfperception of physical competences in preadolescent overweight chinese children. European Journal of Clinical Nutrition, 2004; 59(2): 101-106.

25. Tiggemann M, Williamson S. The effect of exercise on body satisfaction and self-esteem as a function of gender and age. Sex Roles, 2000; 43(2): 119-27.

26. Tritshler K. Practical measurement and Assessment. Liponcott Williams \& Wilkins, Philadelphia, 2000; 409-421

27. Ware JE, Sherbourne CD. The MOS 36-item short-form health survey (SF-36). I. Conceptual framework and item selection. Medical Care, 1992; 30(6): 473-483.

28. Winstead BA, Cash TE. Reliability and validity of the body self-relations questionnaire: a new measure of body im-age. Paper presented at the Southeastern, Psychological Association Convention, New Orleans, LA. 1984: March.

29. Yentür J. Milli takım düzeyindeki elit bayan sporcuların kişilik yapılarıyla bedenlerini algılama düzeylerinin karşılaştırılması, Yüksek Lisans Tezi, Kırıkkale Üniversitesi
Sağlık Bilimleri Enstitüsü, Beden Eğitimi ve Spor Anabilim Dalı, Kırıkkale, 2004.

30. Zekioğlu A, Mir E, Tatar A. Spor yapan ve sedanter yaşayanlarda çok yönlü beden-self ilişkisi, 9.Uluslararası Spor Bilimleri Kongresi, 3-5 Kasım, Muğla Üniversitesi, 2006; Muğla.

31. Asçı F H, Gökmen H, Tiryaki G, Öner U. Liseli erkek sporcuların ve sporcu olmayanların benlik kavramları. Spor Bilimleri Dergisi, 1993; 1(4): 34-43.

32. Huddy CD, Nieman DC, Johnson RL. Relationship between body image and percent body fat among college male varsity and non-athletes. Perceptual and Motor Skills, 1993; 77(5): 851-857.

33. Çok F. Body image satisfaction in Turkish adolescents. Adolescence, 1990; 25(3): 409-414.

34. Mülazımoğlu Ö, Kirazcı S, Aşçı FH. Body image satisfaction level of artistic gymnasts, rhythmic gymnasts and nonathletes. VII. International Sport Sciences Congress, Antalya, Turkey, 2002; 181. 